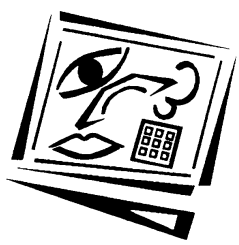

\title{
Learners' attitudes to wiki technology in problem based, blended learning for vocational teacher education
}

Ian Robertson

RMIT University

\begin{abstract}
It would be difficult to argue that the use of online technology to support teaching and learning has not undergone significant change in the last two decades. Recently, with the promotion of social software technologies such as blogs, wikis, podcasts and virtual classrooms, we have seen the emergence of the idea of e-learning 2.0. That is, the use of online technology to support communication, collaboration and knowledge building which are consistent with constructivist principles. The research reported here was conducted in the context of a blended learning approach that incorporates wiki technology and face to face contact to support problem based and group based learning and assessment in a teacher education program at RMIT University, Australia. The results of a post-course survey of learners are used to describe the learners' experience of access to and use of wikis, and their attitudes towards the use of wikis in their own teaching practice over the following 12 months. This discussion is undertaken with consideration to the benefits and difficulties associated with problem based and group based learning and assessment. The learners' attitudes towards the potential use of wikis in their own practices are explored in terms of implementation and professional development.
\end{abstract}

\section{Introduction}

The popularisation of technologies such as wikis, blogs and virtual classrooms, described as social software, has lead to the idea of e-learning 2.0, a term proposed to represent the use of the Internet as a platform for communication, collaboration and knowledge construction rather than the distribution of content (Downes, 2005). This promotion is, at least in part, a response to concerns that e-learning 1.0 has been associated with a transmission or behaviourist style of learning in an environment that generally supports the notion of constructivist learning as the preferred approach (see for example, Bonk \& Dennen, 2007; Juwah, 2006; Richardson, 2006). First developed by Ward Cunningham in 1995, wikis are designed as a solution to making publishing an easy process (Augar, Raitman \& Zhou, 2004; Molyneaux \& Brumley, 2007; Richardson, 2006). Subject to access settings, wikis provide a relatively simple interface that allows web pages to be created and edited by anyone at any time. It is possible to incorporate text, audio, images, video and hyperlinks to other web pages.

This paper reports on the results of a post-course survey of vocational teachers participating in a teacher training program that used a wiki to support problem based, and group based learning and assessment in a blended learning approach (wiki plus face to face contact) in a teacher education program at RMIT University, Melbourne, Australia. The origins, benefits, advantages and disadvantages of problem based learning (see for example, Savin-Baden \& Howell Major, 2004; Uden \& Beaumont, 
2006) and group based learning (see for example, Palloff \& Pratt, 2005; A. Rogers, 2002) have been extensively considered by others. To the extent that, in the current research, wikis are implemented in the context of a problem based and group based environment, consideration will be given to these topics. However, the primary focus will be on wikis and their use in education.

The paper provides a survey of literature on the use of wikis in education. Analysis of the post-course survey of learners (Appendix 1) provides information on learner's experiences of access to and the use of wikis. Learner's attitudes towards the use of wikis in their own teaching practice over the following 12 months are also reported. The implications of the findings for future use of wikis to support problem based, group based learning and assessment in the teacher education program are considered. Broader implications for the implementation and professional development are explored.

\section{Wikis in the current project}

Facilitating Learning in the Workplace is a 39 hour subject conducted over 13 weeks within the Graduate Diploma in Industrial Education and Training at RMIT University. This is equivalent to one quarter of a full time study load. Broadly speaking, the aims of Facilitating Learning in the Workplace are to assist learners to conceptualise and articulate the principles that underpin workplace learning, engage in relevant contemporary debates, and to provide a set of practical strategies to engage in workplace teaching and learning. It is offered in face to face mode. The first eight sessions are lecture and tutorial based. They aim to provide exposure to a range of theories, models and discussions about workplace learning. This part of the course is assessed using an individual written assignment which forms $60 \%$ of the total mark for the course.

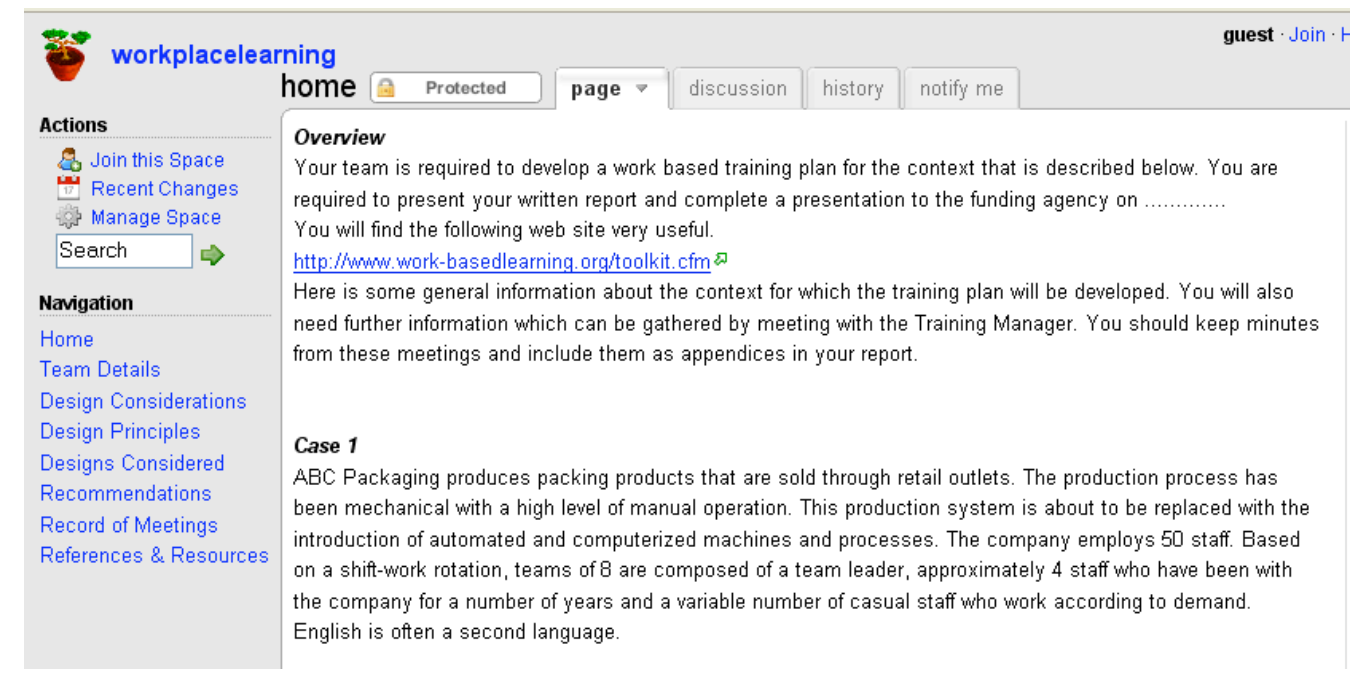

Figure 1: Wiki homepage and case study example

The remaining five sessions involve the completion and presentation of a problem based and group based case study that incorporates the use of a wiki. Groups of 4-5 participants are allocated to establish a representation characterised by diversity in 
gender, age, experience and employment location. Participants employed at the same organisation or similar teaching areas are placed in different groups. Each group includes at least one participant with some experience of teaching in a workplace setting. Case examples are designed to represent the complexity of workplace learning environments and groups are allocated a specific case example that commences with minimal detail. Given the knowledge of workplace learning that students bring to the course, and understandings developed in the first few sessions each group is required to develop a staff training plan for a given scenario. This assignment forms $40 \%$ of the total mark for the course. A screenshot of the wiki homepage with a case study example is given in Figure 1.

An induction session that provides learners with a briefing on how the groups might operate, and, access and use of the wiki is conducted at the commencement of the case study. The importance of considering group dynamics, roles and processes is stressed. It is suggested that groups should use the scheduled face-to-face sessions primarily to meet, discuss and make progress on issues associated with the development of the training plan. Contributions and editing of the wiki should be done either once the meeting is completed or outside of scheduled class time. Given that the case examples contain minimal information, groups are instructed to consider and identify further information that is required and to make an appointment for a face to face meeting with the teacher on a weekly basis to provide the additional information that they require.

Groups are also given an introduction on how to access and use the pre-prepared wiki shell that includes a home page, team details, design considerations, design principles, designs considered, recommendations, record of meetings, references and resources that are found in Figures 2-8. These pages form the major sections of the training plan which is developed over a period of 4-5 weeks and reported through the wiki. They are designed to scaffold the development of the training plan. Participants are informed that they should feel free to add to or change the page headings. Wikis were developed on http://www.wikispaces.com/ and located outside of the RMIT University web site. They are visible to the public but configured so that only group members and the teacher can contribute to and edit the wiki.

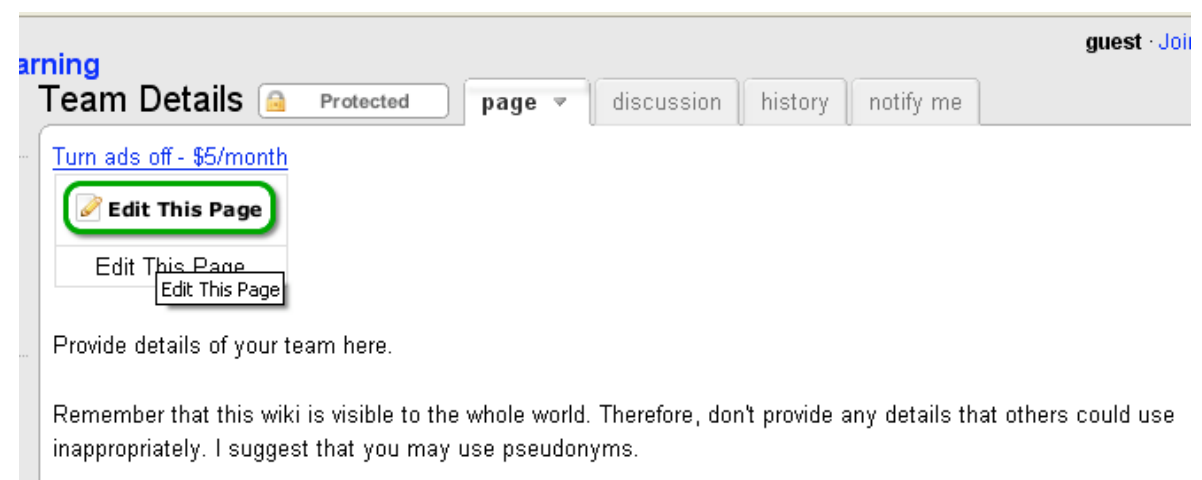

Figure 2: Team details page 


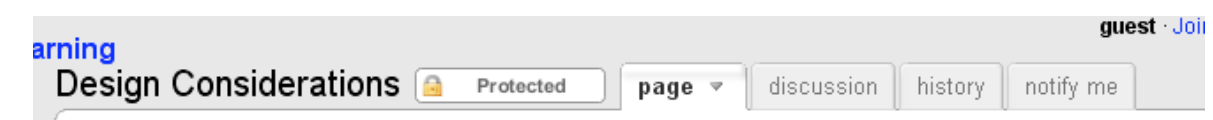

On this page you should document the factors that you have considered in the design of your design solution(s)

- What factors did you consider?

- What was the importance of each factor?

- How did each factor influence your design principles?

It would be useful to include an introduction which describes how you decided which factors to consider. Did you use a particular framework or was it hit and miss?

Figure 3: Design considerations page

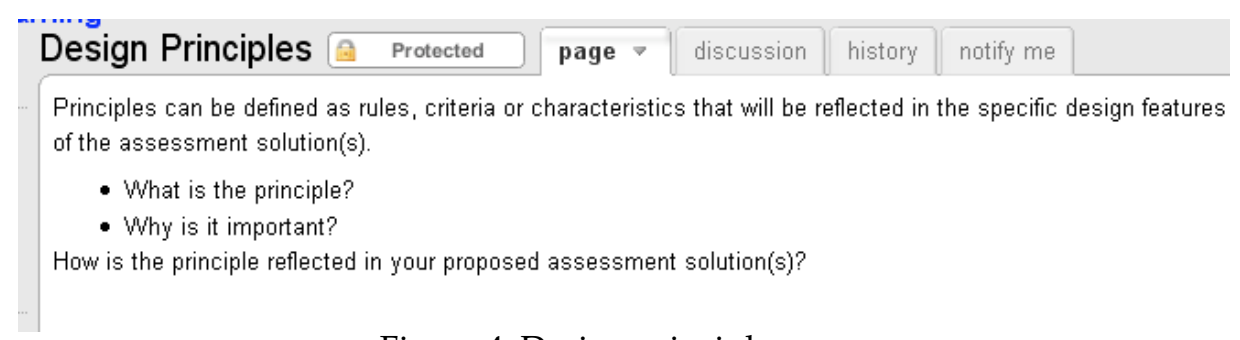

Figure 4: Design principles page

\begin{tabular}{|c|c|c|c|}
\hline Designs Considered Protected & $\begin{array}{ll}\text { page } & \text { discussion }\end{array}$ & history & notify me \\
\hline \multicolumn{4}{|c|}{$\begin{array}{l}\text { On this page you should document each of the design solutions that you considered in coming to a fir } \\
\text { decision (recommendation) for the approach that you recommend. }\end{array}$} \\
\hline
\end{tabular}

Figure 5: Design considerations page

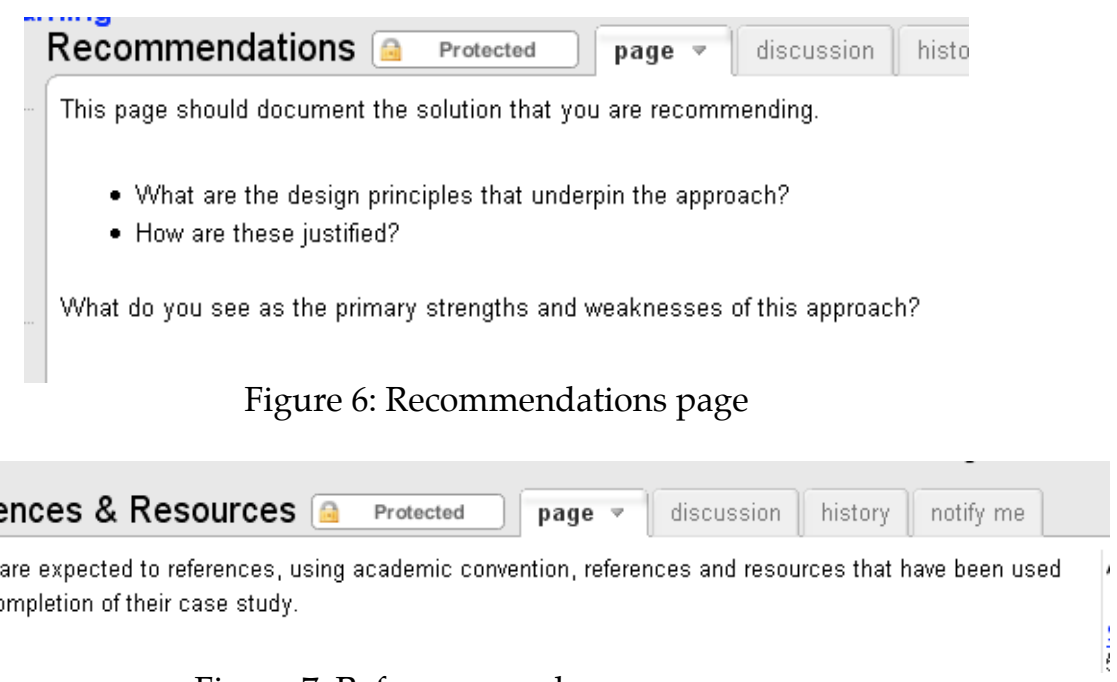

Figure 7: References and resources page 


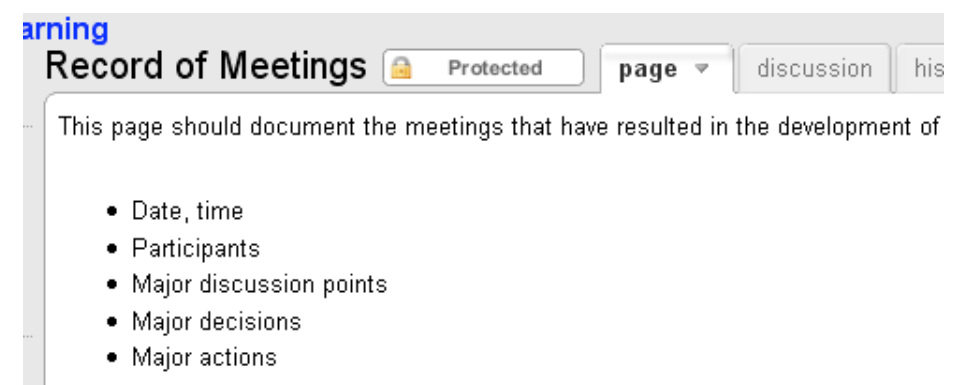

Figure 8: Record of meetings page

The submitted training plans are largely in text form with tables and graphics where appropriate. On completion, a group mark is provided for the training plan on the basis of presentation and content. Peer assessment is also conducted with each group participant rating their own and other group member's contributions to the final work. Individual grades are calculated on the basis of the group mark and modified according to individual contributions.

\section{Findings}

The potential of wikis to support collaborative learning is often received with a high level of optimism. For example, 'wikis are an excellent tool for collaboration in an online environment' (Augar et al., 2004, abstract), 'the efficacy of wikis is self evident (Choy \& Ng, 2007, p.209), and 'we now have access to an enabling suite of tools to support greater learner choice and self direction' (McLoughlin \& Lee, 2007, p.710). However, this potential has yet to be realised (Schwartz, Clark, Cossarin, \& Rudolph, 2004) and a 2007 report predicts that mainstream use of wikis in higher education is two to five years away (Zastrocky, Harris et al, 2007 cited in Kennedy et al., 2007).

In preparing the current paper, a search of eight major educational databases using the terms 'wiki' and 'education' found 633 publications which broadly fall into the categories of promotion, description, technical matters and declarations about the future use of wikis. Other concerns include implications of wiki technology in matters such as the nature of legitimate knowledge and publication, and copyright. Reports that are based on feedback from students are difficult to find. The only example sourced for this paper is based on interviews with three tutors and five students associated with the implementation of a wiki system as a supplement to support a distance, online learning course in an MBA program (Choy \& Ng, 2007).

Given the rapidly changing nature of the use of technology in education and the common delays in gaining publication in peer reviewed journals, a search of all papers presented at the 2007 Australasian Society for Computers in Learning in Tertiary Education (Ascilite) conference was conducted. It was anticipated that, if empirical studies were emerging then reports may be evident in conference proceedings. This was not the case. From a total of 128 conference papers, eight use wiki in the title, an additional three papers use the term wiki in their abstract. Three address specific examples of the use in higher education (Elgort, 2007; Jones, 2007; Molphy, Pocknee, \& Young, 2007), and one provides a lecturer's reflections on the use of wikis (Reimann, Kate, \& Weinel, 2007). Only one paper (Kennedy et al., 2007) provides any empirical research from the learners' perspective. This paucity of refereed literature is also found in the case of blogs (Williams \& Jacobs, 2004). 
What follows is an analysis of the responses of fourteen postgraduate students in a teacher training program.

\section{Respondent profile, sample size and research design}

A limitation of the practitioner based research reported here is the small number of respondents. Given that the researcher was also the teacher of the course investigated the surveys were sent by post to the home addresses of a total of 20 prospective respondents. Completed surveys were returned anonymously in reply paid envelopes. This approach was taken to minimise any influence of power relations.

A total of 14 completed surveys were returned, a response rate of $70 \%$. The general profile of respondents is summarised in Table 1 . There is relatively even representation of males and females. The group is primarily 30-39 or $40-49$ years of age. Eleven respondents are employed in a teaching role, nine in a TAFE college and two as a teacher/trainer in industry. Of the remaining three respondents two are in employment and seeking positions as trainers. The remaining respondent is a full time student who will return to industry on completion of their study. Of those respondents who are in teaching positions, more than one half of the group has less than 4 years teaching experience. They teach in the fields of music industry, interior design, health sciences, plumbing, tourism, printing, clothing production and fashion, nursing, retail training and property.

Table 1: Respondent demographics

\begin{tabular}{|l|l|c|}
\hline \multicolumn{2}{|l|}{} & No. \\
\hline Gender & Male & 8 \\
& Female & 6 \\
\hline Age & $20-29$ & 1 \\
& $30-39$ & 6 \\
& $40-49$ & 4 \\
& $50+$ & 2 \\
& No response & 1 \\
\hline Employed as teacher & Yes & 11 \\
& No & 3 \\
\hline Teaching in & TAFE & 9 \\
& Industry & 2 \\
\hline Years in teaching & Not teaching & 3 \\
\hline & $0-4$ & 9 \\
& $5-9$ & 2 \\
& $10-14$ & 1 \\
& $15+$ & 1 \\
& No response & 1 \\
\hline & Beginner & 2 \\
& Intermediate & 7 \\
& Experienced & 5 \\
& Expert & 0 \\
\hline
\end{tabular}

The demographics of this respondent group are not dissimilar to those of a previous survey of 55 participants in the same program (Robertson, 2006a). It is reasonable to suggest that the current respondent group is representative of the general profile of participants enrolled in the Graduate Diploma in Industrial Education and Training, and it may be that the results reported here can be generalised across this group. However, no claim to generalisability beyond this context is made. 
One half of the respondents rate their level of technical skill as intermediate, five describe themselves as experienced and the remaining two describe themselves as beginners. Overall, they report the use of a range of technologies for personal purposes including Internet, email, Facebook, Microsoft Office suite, multimedia software and mobile devices. All respondents report the regular use of at least one technology for teaching. Most frequently cited are the Internet, PowerPoint and a learning management system. Two respondents use specialised technology in the form of mannequins and multimedia software.

Only two respondents have used wikis before. One is not currently in a teaching role and has previously used wikis for personal purposes. The other teaches in the retail training field and has previously used wikis for teaching. Both rate themselves as experienced users of technology.

\section{Ease of access and use}

Table 2 summarises ratings of wikis in respect to ease of access and use. Ten respondents rate wikis as easy to access and four rate access as moderate. No respondent found access difficult or very difficult. Nine rate the use of wikis as easy and four as moderate with a single respondent rating wiki use as difficult.

Table 2: Ease of access and use of wikis

\begin{tabular}{|l|c|c|c|c|c|}
\hline & Easy & Moderate & Difficult & Very difficult & Total \\
\hline Ease of access & 10 & 4 & 0 & 0 & 14 \\
\hline Ease of use & 9 & 4 & 1 & 0 & 14 \\
\hline & Beginner & Intermediate & Experienced & Expert & Total \\
\hline Both access and use of wikis easy & 1 & 5 & 3 & 0 & 9 \\
\hline Both access and use of wikis moderate & 0 & 2 & 2 & 0 & 4 \\
\hline Access to wikis easy, but use difficult & 1 & 0 & 0 & 0 & 1 \\
\hline
\end{tabular}

One might expect that there will be a correlation between self reported technical skill level and the level of difficulty that respondents experience with respect to access to and use of wikis. However, the results here suggest a more complex relationship. Three patterns of response emerged. The nine respondents who rate both access and use of wikis as easy also rate their technical expertise as beginner, intermediate, or experienced. This subgroup includes the respondent who is in a teaching role and has previously used wikis for teaching. The four respondents who rate both access and use of wikis as moderate self assess their level of technical skill as intermediate or experienced. This subgroup includes the individual who is not teaching and has used wikis for personal purposes. The remaining respondent who self evaluates level of technical skill as beginner rates access to wikis as easy but use as difficult.

Overall, those respondents who self reported their technical skill level as intermediate or experienced had little difficulty in either accessing or using the wiki. Only one respondent experienced difficulty in using the wiki and this person rated technical level of skill as beginner. However, rating technical skill level as a beginner is not necessarily a predictor of experiencing difficulty in using the wiki. The other respondent who rated their technical skill level as beginner reported that the wiki was both easy to access and to use. 


\section{Best and worst features and recommendations}

Respondents were invited to identify the best and worst features of wikis, and to make suggestions for improvement. Responses can be broadly categorised as relating to the technical/design features of wikis, the nature of group dynamics, and the role of the teacher.

There is overwhelming support for the flexibility that the wiki provided in allowing learners to access and use the software at a time and place that best suited them. Having access to a single central document where previous edits can be tracked, and the use of the wiki to replace the need for submission of a hard copy report are also identified.

Some found that initial setup and use was not intuitive. Others are disappointed with the capacity of the wiki to accept graphics and the level of Windows/Macintosh compatibility. Other weaknesses and associated recommendations relate to the inclusion of functions more representative of word processing programs such as improved editing and formatting features especially in relations to tables and graphics and a tracking function. One respondent considers that MySpace and Facebook are better communication tools. Another indicates that in some cases the immediacy of email communication is preferable to the use of wikis.

Whilst the capacity of wikis to allow all group members to create and edit content is consistently seen as an advantage, some respondents also find the ease with which any team member can change the wiki content without discussion with other team members as a weakness. Another respondent was concerned that not all group members participated, and became frustrated that there was a need to 'chase people up'. These comments seem to relate more to relationships within the groups, group operation and group dynamics rather the design of the wiki. The role of the teacher in supporting the implementation of the wiki is central to recommendations that there is a need to introduce a quick reference guide/instruction sheet at induction and commencement of the use of the wiki. Further, that greater assistance should be provided with how to use wikis to better support collaboration and learning once the wiki is in use.

\section{The potential of wikis: Postgraduate learner's perspectives}

Table 3 summarises views about the continued and expanded use of wikis in postgraduate study. Review of the surveys reveals four patterns of responses. When these categories are considered against the respondents self reported level of technical skills, and their experience in accessing and using the wiki it is difficult to conclude that there is a predictive relationship between these factors and an individual's level of support for continued or expanded use of wikis in the Graduate Diploma in Industrial Education and Training.

Nine respondents support continued use in the current course and use in other courses. They describe their level of technical expertise as beginner, intermediate or experienced. They found access and use of the wiki either easy or moderate. A further two respondents support the continued use of wikis in the current course but are unsure about use in other courses. They rate their technical expertise as beginner or intermediate, they found access to the wiki easy. In one case the use of the wiki is reported as easy, in the other as difficult. 
Table 3: Continued and expanded use of wikis

\begin{tabular}{|c|c|c|c|c|c|c|c|c|c|c|c|c|}
\hline & & & & & \multicolumn{2}{|c|}{ Yes } & \multicolumn{2}{|c|}{ No } & \multicolumn{2}{|c|}{ Not sure } & \multicolumn{2}{|c|}{ Total } \\
\hline \multicolumn{5}{|c|}{ Support continued use in the program } & \multicolumn{2}{|c|}{11} & \multicolumn{2}{|c|}{0} & \multicolumn{2}{|r|}{3} & \multicolumn{2}{|c|}{14} \\
\hline \multicolumn{5}{|c|}{ Enthusiastic about use in another course } & \multicolumn{2}{|c|}{11} & \multicolumn{2}{|c|}{0} & \multicolumn{2}{|r|}{3} & \multicolumn{2}{|c|}{14} \\
\hline & \multicolumn{4}{|c|}{$\begin{array}{l}\text { Self reported } \\
\text { technical skill }\end{array}$} & \multicolumn{4}{|c|}{$\begin{array}{c}\text { Ease of access } \\
\text { to wiki }\end{array}$} & \multicolumn{4}{|c|}{$\begin{array}{c}\text { Ease of use } \\
\text { of wiki }\end{array}$} \\
\hline & $\begin{array}{l}\text { begi- } \\
\text { nner }\end{array}$ & $\begin{array}{l}\text { inter- } \\
\text { med- } \\
\text { iate }\end{array}$ & $\begin{array}{c}\text { expe- } \\
\text { rien- } \\
\text { ced }\end{array}$ & $\begin{array}{l}\text { exp- } \\
\text { ert }\end{array}$ & easy & $\begin{array}{l}\text { mod- } \\
\text { erate }\end{array}$ & $\begin{array}{c}\text { diffi- } \\
\text { cult }\end{array}$ & $\begin{array}{l}\text { very } \\
\text { diff- } \\
\text { icult }\end{array}$ & easy & $\begin{array}{l}\text { mod- } \\
\text { erate }\end{array}$ & \begin{tabular}{|l|} 
diff- \\
icult
\end{tabular} & $\begin{array}{l}\text { very } \\
\text { diff- } \\
\text { icult }\end{array}$ \\
\hline $\begin{array}{l}\text { Support continued use in } \\
\text { current course and use in } \\
\text { other courses }\end{array}$ & 1 & 4 & 4 & 0 & 7 & 2 & 0 & 0 & 7 & 2 & 0 & 0 \\
\hline $\begin{array}{l}\text { Support continued use in } \\
\text { current course, unsure about } \\
\text { use in other courses }\end{array}$ & 1 & 1 & 0 & 0 & 2 & 0 & 0 & 0 & 1 & 0 & 1 & 0 \\
\hline $\begin{array}{l}\text { Not sure about continued use } \\
\text { in current course, would be } \\
\text { enthusiastic about use in } \\
\text { other courses }\end{array}$ & 0 & 1 & 1 & 0 & 0 & 2 & 0 & 0 & 0 & 2 & 0 & 0 \\
\hline Not sure in both cases & 0 & 1 & 0 & 0 & 1 & 0 & 0 & 0 & 1 & 0 & 0 & 0 \\
\hline
\end{tabular}

Two other respondents are unsure about the continued use of the wiki in the current course but are enthusiastic about use in other courses. They rate their technical expertise as either intermediate or experienced, and found access and use of the wiki moderate. The remaining respondent is unsure about the continued use of the wiki in the current course and use in other courses. This person rates technical expertise as intermediate and rates both access and use of the wiki as easy.

Therefore, responses to questions regarding the continued use of wikis in the current course and expansion into other courses reflect support for both propositions. Whilst three respondents are unsure about continued use in the current course or expansion into other courses, no respondent indicated that wikis should be discontinued from either the course related to this research or the program more broadly.

A predictive relationship between an individual's self reported level of technical skill or experience in accessing or using the wiki and views about the continued or expanded use of wikis in the Graduate Diploma in Industrial Education and Training cannot be supported on the basis of these limited data. Even the respondent with a self reported technical skill level of beginner, who found access to the wiki easy but use difficult, supports continued use of the wiki in the current course. Another who rates technical expertise as intermediate, and, access and use of the wiki as easy, is unsure about continued use in the current course or other courses. In another case, a respondent who rates technical expertise as experienced, and, access and use of the wiki as moderate is not sure about the use of the wiki in the current course but supports use in other courses.

\section{The potential of wikis: Teacher's perspectives}

Table 4 summarises respondent's views about the potential use of wikis in their own teaching and the likelihood of use in the next 12 months.

Eight respondents indicate that wikis have potential in their own teaching. They self evaluate their technical skill level as beginner, intermediate or experienced. They 
found access to and use of wikis easy or moderate. One person is not currently in a teaching role. Of this group, four intend to use this technology in the next 12 months. These individuals are currently teaching, they found wikis easy to access and use, and support continued and expanded use in the current program. Three rate their technical level as experienced and one as a beginner. Three work in a TAFE college and one in industry. They suggest that they might use wikis to support discussion, group case studies and assignments, as a supplement to participation in face to face classes, as a journal of completed work, and as a forum for product development and quality testing (a content vehicle rather than a communication tool) and for easier distribution of hard copies.

Table 4: Use of wikis in own teaching

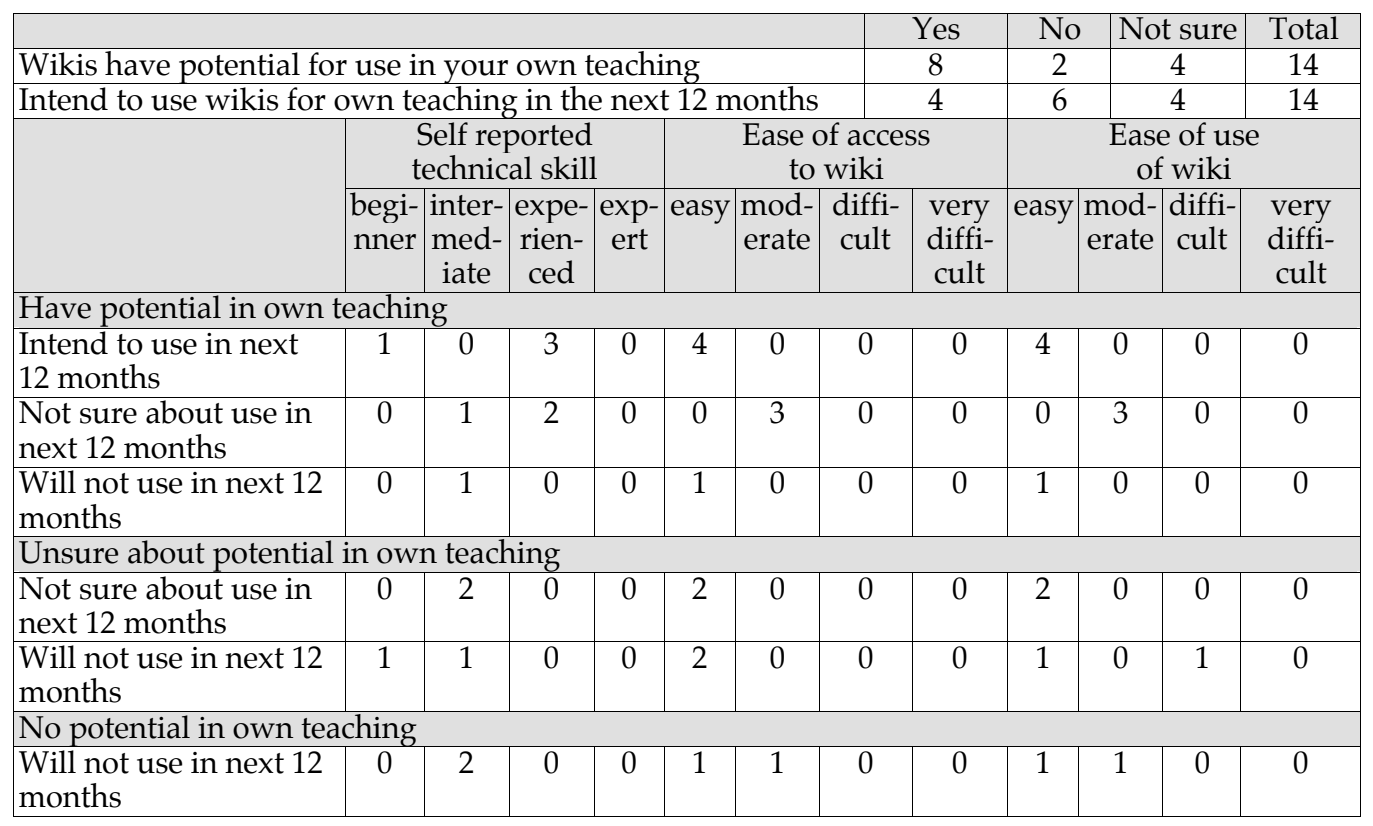

A further three respondents who identify wikis as having potential in their own teaching are unsure about their use in the next 12 months. They rate their technical skill level as intermediate or experienced, and described wikis as moderate to access and use. The remaining respondent who sees wikis as having potential in their own teaching does not intend to implement in the next 12 months. This respondent rates technical skill level as intermediate and found the wiki easy to access and use.

Four respondents indicate that they are unsure about the potential use of wikis in their own teaching. One is not currently teaching. Three of these four respondents rate their technical skill as intermediate, the remaining respondent as beginner. All found the wiki easy to access. Those who are unsure about use in the next 12 months rate use as easy. Two respondents indicate that wikis do not have potential in their own teaching. They rate their technical skills as intermediate, and, found the wiki easy or moderate to access and use.

Comparison of self reported technical skill level and perceived potential of wikis in the respondents' own teaching finds that all five respondents who self evaluate their 
technical skill level as experienced also identify wikis as having potential in their own teaching. Three intend to use wikis in the next 12 months; they all rate the access and use of wikis as easy. The two remaining respondents who rate their technical skill level as experienced are unsure about implementation in the next 12 months. They rate access and use of wikis as moderate.

On the basis of this sample, it is reasonable to propose that respondents who rate their technical skill level as experienced are most likely to perceive a potential for wikis in their own teaching. They either intend to, or are unsure about the implementation of wikis in their own practice in the next 12 months. However, self evaluation as a beginner is not a predictor of a lack of support for the use of wikis in one's own teaching. Of the two respondents who rate their technical skill level as beginner, one is unsure about the use of wikis in their own practice in the next 12 months, the other is positive about this potential and intends to implement in the next 12 months. Here, the respondent's experience of wiki seems to inform the likelihood of implementation. The person who intends to implement in the next 12 months found the wiki easy to access and use, the other experienced difficulty in use.

\section{Discussion: Wiki functionality, learner and teacher roles, and implications for professional development}

This discussion focuses on three aspects of wikis in supporting problem based and group based learning and assessment: the design and functionality of wikis; the roles of learners and teachers for the successful implementation; and, the implications of this study for teacher professional development.

As learners, the participants in this study found wikis easy to access and for most people easy to use. They value the flexibility that wikis provide in terms of access, content development and editing, appreciate a single central document for group work and the replacement of hard copy with electronic submission. Recommendations for improvement to wiki design are mostly in the form of desiring increased functionality rather than being critical of existing design. The respondent group is overwhelmingly in support of the continued and/or expanded use of wikis in other courses in the Graduate Diploma in Industrial Education and Training. These findings are consistent with the proposition that innovations are more likely to be adopted if they are useful and easy to use (Davis, 1989). Also that wikis provide a relative advantage over existing practice, lack complexity and are compatible with needs. It is reasonable to propose that in the process of using the wiki as part of a problem based and group based activity the respondents have been able to trial its use as a learner and observe some benefit (E. Rogers, 1995). The responses also warn that this group does not universally support the wholesale use of wikis across a curriculum, a finding that is consistent with the proposition that wikis should not be used without due consideration to their appropriateness for the particular circumstances (Elgort, 2007; Jones, 2007).

As teachers, more than one-half of the respondents identify wikis as having potential in their own teaching, and one-half of these intend to implement in the next 12 months. Whilst the sample is small, this finding goes some way to supporting the optimism which some pronounce about the potential of wikis in teaching. A positive view on the use of wikis is typified by one respondent who commented that there is fantastic potential for the use of wiki to encourage the ease of group work'. Further analysis 
shows that a self reported technical skill level of experienced, and feedback that wikis are easy to access and use is most likely be associated with respondents who see a possible use of wikis in their own teaching and have an intention to implement wikis in the next 12 months.

Unsurprisingly, wikis are not a solution to difficulties associated with group based assignments. At least one group of respondents reported here failed to develop group dynamics that support collaborative learning and this was reflected in the quality of the training plan that was submitted for assessment. As inferred by one respondents who commented that 'the best part about the actual group assignments was that we achieved a lot during class, had clear tasks and could then go off and do independent work', the success of wikis in group based activities is dependent on the success of group operations and dynamics. These findings are consistent with a recognition that the role of the teacher is central to the success of wiki implementation. Some respondents recommend more effective induction into the use of the wiki, and, greater assistance in how to use of the wiki in a productive manner. The role of the teacher should be clear (Choy \& Ng, 2007), adequate technical and pedagogic support must be provided. However, if problem based learning is to be learner centred and constructivist, there is a need to ensure that teacher direction does not constraint the learners use of the wiki (Elgort, 2007).

Through the categories of innovators, early adopters, early majority, late majority and laggards, Rogers (1995) provides a set of characteristics to describe people's disposition towards the adoption of innovation. It is not unreasonable to suggest that respondents who self report their level of technical expertise as experienced are more likely to be early adopters and have a relatively positive disposition towards the use of technology. However, self evaluation as a beginner in technical skill level is not prohibitive. In this study, one respondent who self rates as a beginner and found wikis easy to access and use, intends to implement in the next 12 months. Therefore, it would be unwise to assume that people with a self reported level of expertise as beginner will not intend to adopt wikis as a result of professional development.

With specific concern for factors that promote the adoption of online technology in teaching, Robertson (2006b) describes disposition as a factor that acts as a backdrop against which three other factors operate. Teachers also need to be aware of the potential of the technology in their practice, and, identify an authentic and meaningful opportunity for implementation in the face of perceived adequate support. Awareness may be developed through a short information session, longer professional development activities or as a result of transfer from personal use of the technology. The time delay between the development of awareness and the emergence of the opportunity is less important than the authenticity and meaningfulness of the opportunity to the individual teacher. This opportunity may be sponsored by an organisation or self initiated. The level of support required varies from individual to individual. In some cases adequate support is merely the removal of barriers, in others there is a need for human, physical, technical and financial support (Robertson, 2006b). Rogers (1995) describes the process of the adoption of innovation as five steps: knowledge, persuasion, decision, implementation and confirmation. In order to adopt an innovation people must be aware of its existence and be provided with enough information to develop an interest in its use. Once an interest is developed people evaluate the usefulness of the innovation in terms of relative advantage compared with existing practices, compatibility with existing values and needs, and, the level of complexity of the innovation. Having developed an awareness and interest, and 
having decided that the innovation may be of positive use, the innovation is trialed. If observable benefit is confirmed, use of the innovation is likely to continue.

The findings of this study show that the use of the wiki in Facilitating learning in the workplace has provided participants with the opportunity to develop an awareness of the potential of the technology. That is, the possibility of using wikis in personal teaching practice has been primed. It is likely that those who perceive wikis as having potential for use in their own teaching and intend to implement in the next 12 months have identified an opportunity for implementation where they can trial and observe the use of wikis, and, expect to be provided with an adequate level of support to engage in this activity. Where wikis are perceived as useful in a respondents own practice but they do not intend to implement in the next 12 months it is likely that an opportunity has not been identified and/or the person does not expect the required support for implementation in the near future.

This discussion concludes that wikis embed a set of characteristics that are consistent with adoption by teachers. That is, they can be perceived to provide a relative advantage over existing practices when applied to problem based and group based activities. They lack complexity, are flexible enough to be compatible with a range of teaching strategies, can be trialed easily and the results can be observed easily. Given that teachers are reasonably disposed to and aware of the possible use of technology in their practice, the technology may be adopted in the presence of a meaningful and authentic opportunity where there is perceived to be an adequate level of support. The role of professional development is generally identified as a critical factor in supporting the implementation of technologies.

A recent review of teacher professional development finds that activities that aim to change practice should use content that is relevant to the participants, provide examples of new pedagogy in action, provide support and time for changes in teacher's understanding and commitment to new practices, recognise the influence of established expectations and norms, and establish an environment where participants feel safe to share ideas and examples of work (Harlen \& Doubler, 2007). The activity examined in this paper, that is, the use of a wiki in a teacher preparation, embeds a number of the factors for professional development proposed by Harlen \& Doubler (2007). The use of the wiki is based on a case example that is authentic in nature, relevant to participants who are interested in workplace based learning, and models new practice. Groups were established in an attempt to create safe environments with a diversity of participants such that ideas and practical examples could be exchanged in the development of a staff training plan. The quality of the final training plans and the observed level of cooperation amongst group members suggest that a suitable environment was created with the exception of one group where personalities and ideas conspired against an entirely satisfactory group dynamic. The participants' lack of previous exposure to wikis in personal or professional activities also suggest that the case example reported was conducted over a timeframe that was adequate to provide participants with an opportunity to be aware of, develop an interest in, and make a decision about the potential use of wikis. That is, they have experienced the knowledge, persuasion and decision steps as proposed by Rogers (1995). The remaining stages of implementation and confirmation will need to occur elsewhere.

As has already been shown, teacher's disposition towards the use of technology in teaching is fundamental to decisions about adoption. Despite the limitations of variations in terminology, there is a strong body of literature to support the contention 
that teacher's deep seated notions of what constitutes good teaching are critical in shaping teacher's practice. Terms include values, beliefs (Borko \& Putnam, 1995; Errington, 2004; Pajares, 1992; Schoenfeld, 1998) and personal practical theories (Marland, 1997, 1998). It is also generally recognised that teachers bring values and beliefs about teaching to practice from their experience as learners. These are often developed by the time people leave secondary school and are difficult to change (Pajares, 1992). Whilst general pedagogic knowledge can be described as generic and largely procedural knowledge (Turner-Bisset, 2001), pedagogical content knowledge, which differentiates novice from expert teachers (Shulman, 1987), is underpinned by values and beliefs about what constitutes good teaching practice and is largely developed on the job, when teachers work in different contexts over a period of time (Gudmundsdottir, 1995). Therefore, if professional development of teachers is to fundamentally change teacher's practice there is a need to move beyond simply providing technical level skills in the use of a technology and strategies for using the technology in an educational setting to address teacher's beliefs about what constitutes good teaching practice (Errington, 2001, 2004; Marland, 1997, 1998; Pratt, 1998). Such an approach to professional development requires practitioners to engage 'in dialogue about personal practical theories of learning and teaching' (Errington, 2004, p.43) in order to 'subject their theories to review and revision' (Marland, 1998, p.18) so that sustainable changes in teaching practice can occur. Whilst teacher's technical expertise is likely to be influential in shaping their use of technologies for teaching, professional development that merely addresses technical skills and instrumental strategies is unlikely to support sustainable change in teaching practice. The case example provided in this paper goes some way to modeling such an approach.

\section{Conclusion}

Based on a small scale study of postgraduate learners in a teacher training program who have used a wiki to support problem based and group based learning in a blended learning model, this paper concludes that the design and functionality of wikis is consistent with characteristics that promote adoption. Whilst respondents have recommendations for improvement, these are more in the nature of 'wanting more' rather than being critical of what currently exists. They also make recommendations about the role of the teacher that have the potential to improve the learners' experience. Using research on factors that support the adoption of technology for teaching it is concluded that the use of the wiki in Facilitating learning in the workplace is consistent with promoting awareness, providing participants with an opportunity to assess the technology for further use, and to be able to make a decision about potential use on their own practice as teachers.

More than half of the respondents perceive that wikis have potential in their own teaching and one-half of these intend to implement in the next 12 months. This finding is discussed in respect to individual disposition towards the use of technology and factors that support the adoption of technology for teaching. The research finds that respondents who self evaluate their technical skill level as experienced are most likely to intend to use wikis in their own teaching but that self evaluation as a beginner is not necessarily prohibitive. When this and other factors are considered in respect to professional development programs that aim to promote sustainable and meaningful change in teaching practice it is concluded that, in addition to technical and instrumental concerns, professional development must also address the values and beliefs that underpin a teacher's practice. 


\section{References}

Augar, N., Raitman, R. \& Zhou, W. (2004). Teaching and learning online with wikis. In Beyond the comfort zone. Proceedings 21st ASCILITE Conference (pp. 95-104). Perth, 5-8 December. http: / / www.ascilite.org.au/conferences / perth04/procs/augar.html

Bonk, C. \& Dennen, V. (2007). Frameworks for design and instruction. In M. G. Moore (Ed.), Handbook of distance education (2nd ed., pp. 233-246). Pennsylvania: Lawrence Erlbaum.

Borko, H. \& Putnam, R. (1995). Expanding teacher's knowledge base. A cognitive psychology perspective on professional development. In T. Guskey \& M. Huberman (Eds.), Professional development in education. New paradigms and practices (pp. 35-66). Colombia University: Teachers College Press.

Choy, S. O. \& Ng, K. C. (2007). Implementing wiki software for supplementing online learning. Australasian Journal of Educational Technology, 23(2), 209-226. http: / / www.ascilite.org.au/ajet/ajet23/choy.html

Davis, F. (1989). Perceived usefulness, perceived ease of use, and user acceptance of information technology. MIS Quarterly, 13, 319-340.

Downes, S. (2005). E-learning 2.0. eLearn Magazine, 17 October [verified 18 July 2008] http: / / www.elearnmag.org / subpage.cfm?section=articles\&article=29-1

Elgort, I. (2007). Using wikis as a learning tool in higher education. In ICT: Providing choices for learners and learning. Proceedings ascilite Singapore 2007. http: / / www.ascilite.org.au/conferences/ singapore07/procs/elgort.pdf

Errington, E. (2001). The influence of teacher beliefs on flexible learning innovation in traditional university settings. In F. Lockwood \& A. Gooley (Eds.), Innovation in open and distance learning: Successful development of online and web-based learning (pp. 27-37). London: Kogan Page Ltd.

Errington, E. (2004). The impact of teacher beliefs on flexible learning innovation: Some practices and possibilities for academic developers. Innovations in Education and Teaching International, 41(1), 39-47.

Gudmundsdottir, S. (1995). The narrative nature of pedagogic content knowledge. In $\mathrm{H}$. McEwen \& K. Egan (Eds.), Narrative in teaching, learning and research (pp. 24-38). New York: Teachers College.

Harlen, W. \& Doubler, S. (2007). Researching the impact of online professional development of teachers. In R. Andrews \& C. Haythornthwaite (Eds.), The SAGE handbook of e-learning research (pp. 466-486). Los Angeles: Sage.

Jones, P. (2007). When a wiki is the way: Exploring the use of a wiki in a constructively aligned learning design. In ICT: Providing choices for learners and learning. Proceedings ascilite Singapore 2007. http:/ / www.ascilite.org.au/conferences/ singapore07/ procs/jones-p.pdf

Juwah, C. (Ed.) (2006). Interactions in online education. Implications for theory and practice. London: Routledge.

Kennedy, G., Dalgarno, B., Gray, K., Judd, T., Waycott, J., Bennett, S., Maton, K., Krause, K.L., Bishop, A., Chang, R. \& Churchward A. (2007). The net generation are not big users of Web 2.0 technologies: Preliminary findings. In ICT: Providing choices for learners and learning. Proceedings ascilite Singapore 2007. http: / / www.ascilite.org.au/conferences/ singapore07/ procs/kennedy.pdf

Marland, P. (1997). Towards more effective open and distance teaching. London: Kogan Page.

Marland, P. (1998). Teachers' practical theories: Implications for preservice teacher education. Asia-Pacific Journal of Teacher Education and Development, 1(2), 15-23. 
McLoughlin, C. \& Lee, M. (2007). Social software and participatory learning: Pedagogical choices with technology affordances in the Web 2.0 era. In ICT: Providing choices for learners and learning. Proceedings ascilite Singapore 2007.

http: / / www.ascilite.org.au/conferences / singapore07/ procs/mcloughlin.pdf

Molphy, M., Pocknee, C. \& Young, T. (2007). Online communities of practice: Are they principled and how do they work? In ICT: Providing choices for learners and learning. Proceedings ascilite Singapore 2007. http: / / www.ascilite.org.au/conferences/singapore07/procs/molphy.pdf

Molyneaux, T. \& Brumley, J. (2007). The use of wikis as a management tool to facilitate group project work. In Proceedings AAEE: 18th Annual Conference of the Australasian Association for Engineering Education, Melbourne, 9-13 December. http: / / www.cs.mu.oz.au/aaee2007/ papers/ paper_58.pdf

Pajares, F. M. (1992). Teachers' beliefs and educational research: Cleaning up a messy construct. Review of Educational Research, 62(3), 307-332.

Palloff, R. \& Pratt, K. (2005). Collaborating online: Learning together in community. San Francisco: Jossey-Bass.

Pratt, D. (1998). Five perspectives on teaching in adult and higher education. Malabar: Krieger Publishing Company.

Reimann, P., Kate, T. \& Weinel, M. (2007). Collaborative learning by modelling: Observations in an online setting. In ICT: Providing choices for learners and learning. Proceedings ascilite Singapore 2007. http: / / www.ascilite.org.au/conferences/singapore07/ procs/reimann.pdf

Richardson, W. (2006). Blogs, wikis, podcasts, and other powerful web tools for classrooms. Thousand Oaks, CA: Corwin Press.

Robertson, I. (2006a). Deconstruction, confusion and frequency: Surveying technology use by vocational teachers. In Global VET: Challenges at the Global, National and Local Levels. Proceedings 9th Annual AVETRA Conference, 19-21 April, University of Wollongong. http:/ / www.avetra.org.au/ABSTRACTS2006/PA\%200031.pdf

Robertson, I. (2006b). Teachers integrating online technology in TAFE. Unpublished Doctor of Education thesis, Monash University, Melbourne.

Rogers, A. (2002). Teaching adults (3rd ed.). Buckingham: Open University Press.

Rogers, E. (1995). Diffusion of innovations (4th ed.). New York: The Free Press.

Savin-Baden, M. \& Howell Major, C. (2004). Foundations of problem-based learning. Maidenhead: Open University Press.

Schoenfeld, A. (1998). Toward a theory of teaching-in-context. Issues in Education, 4(1), 1-94.

Schwartz, L., Clark, S., Cossarin, M. \& Rudolph, J. (2004). Educational wikis: Features and selection criteria. The International Review of Research in Open and Distance Learning, 5(1). http:/ / www.irrodl.org/index.php/irrodl/article/view/163/244

Shulman, L. (1987). Knowledge and teaching: Foundations of the new reform. Harvard Educational Review, 57(1), 1-22.

Turner-Bisset, R. (2001). Expert teaching: Knowledge and pedagogy to lead the profession. London: David Fulton Publishers.

Uden, L. \& Beaumont, C. (2006). Technology and problem-based learning. Hershey, PA: Information Science Publishing.

Williams, J. \& Jacobs, J. (2004). Exploring the use of blogs as learning spaces in the higher education sector. Australasian Journal of Educational Technology, 20(2), 232-247. http: / / www.ascilite.org.au/ajet/ajet20/williams.html 


\section{Appendix 1: Survey of learner experience of wiki use in a teacher education program}

\begin{tabular}{|l|l|}
\hline 1 & Are you employed in a teaching role?
\end{tabular}

2 Are you employed in?

Yes O No O

RMIT O Other TAFE O Private provider O

Other $\mathrm{O}$

3 Gender

4 Age

Male $\mathrm{O}$ Female $\mathrm{O}$

5 How many years have you been in a teaching role?

6 How would you rate your level of technical skill in using computers?

20-29 O $30-39$ O $\quad 40-49$ O $\quad 50+0$

$0-4 \mathrm{O} \quad 5-9 \mathrm{O} \quad 10-14 \mathrm{O} \quad 15+\mathrm{O}$

7 Please identify the main vocational

Beginner $\mathrm{O}$ Intermediate $\mathrm{O}$ Experienced $\mathrm{O}$

discipline in which you teach e.g. plumbing, graphic design

8 Have you used a wiki for any of the following in the past?

Expert O

\begin{tabular}{|c|c|c|}
\hline & following in the past? & $\begin{array}{l}\text { Wiki for teaching } \mathrm{O} \\
\text { Wiki as a learner O } \\
\text { Never used wiki before O }\end{array}$ \\
\hline 9 & $\begin{array}{l}\text { Please list technologies that you } \\
\text { regularly use for personal purposes }\end{array}$ & \\
\hline 10 & $\begin{array}{l}\text { Please list technologies that you } \\
\text { regularly use for teaching purposes }\end{array}$ & \\
\hline 11 & How easy was it to access the wiki? & Easy $\mathrm{O}$ Moderate $\mathrm{O}$ Difficult $\mathrm{O}$ Very Difficult $\mathrm{O}$ \\
\hline 12 & How easy was it to use the wiki? & Easy $\mathrm{O}$ Moderate $\mathrm{O}$ Difficult $\mathrm{O}$ Very Difficult $\mathrm{O}$ \\
\hline 13 & $\begin{array}{l}\text { List the best features of using a wiki for } \\
\text { a group assignment }\end{array}$ & \\
\hline 14 & $\begin{array}{l}\text { List the worst features of using a wiki } \\
\text { for a group assignment }\end{array}$ & \\
\hline 15 & $\begin{array}{l}\text { Would you support the continued use } \\
\text { of wikis in the GC/GDIET }\end{array}$ & Yes O No O Not Sure O \\
\hline 16 & $\begin{array}{l}\text { Would you be enthusiastic about using } \\
\text { wikis in another course (as a learners)? }\end{array}$ & Yes O No O Not Sure O \\
\hline 17 & $\begin{array}{l}\text { List suggestions for improvements in } \\
\text { how the wiki was used in your course } \\
\text { of study }\end{array}$ & \\
\hline 18 & $\begin{array}{l}\text { Do you believe that wikis have } \\
\text { potential for your own teaching? }\end{array}$ & Yes O No O Not Sure O \\
\hline 19 & $\begin{array}{l}\text { Do you intend to use wikis for your } \\
\text { own teaching the next } 12 \text { months? }\end{array}$ & Yes O No O Not Sure O \\
\hline 20 & $\begin{array}{l}\text { If yes to Q16 or } 17 \text { please indicate how } \\
\text { the wiki might be used }\end{array}$ & \\
\hline
\end{tabular}

Please add further comments.

Dr Ian Robertson, Senior Lecturer, School of Education, RMIT University, Swanston Street, Melbourne Vic 3000, Australia. Email: Ian.robertson@rmit.edu.au 